\title{
Processing of a LLDPE/HDPE Pressure Vessel Liner by Rotomolding
}

\author{
E. S. Barboza Neto , L. A. F. Coelho , M. M. C. Forte , S. C. Amico , C. A. Ferreira ${ }^{\text {a* }}$ \\ a Laboratório de Materiais Poliméricos, Programa de Pós-graduação em Engenharia de Minas \\ Metalúrgica e de Materiais, Universidade Federal do Rio Grande do Sul-UFRGS, \\ Av. Bento Gonçalves, 9500, CEP 91509-900, Porto Alegre, RS, Brasil \\ ${ }^{\mathrm{b}}$ Centro de Ciências Tecnológicas - CCT, Universidade do Estado de Santa Catarina - UDESC, \\ CEP 89223-100, Joinville, SC, Brasil
}

Received: March 8, 2013; Revised: September 1, 2013

\begin{abstract}
Biaxial rotational molding is a low-pressure process that uses a polymer powder to produce large and/or complex-shaped hollow thermoplastic goods using low cost molds, being very suitable for prototype production. In the present work, liner prototypes $(\Phi 78 \times 280 \mathrm{~mm})$ made of linear low density (LLDPE) and high density polyethylene (HDPE) blends were produced aiming to later use them as compressed natural gas type IV cylinders. The LLDPE/HDPE blend composition and the process parameters (temperature/time cycle, and rotation speed) were varied to evaluate their effect on blend miscibility and liner final properties, such as density and crystallization behavior. Blend composition and process parameters were found vital for the production of a homogeneous wall and for the liner to reach adequate characteristics for the intended product.
\end{abstract}

Keywords: polyethylene, HDPE, LLDPE, blends, liner, pressure vessel, rotomolding

\section{Introduction}

Liners used for composite pressure vessels may be obtained by rotomolding instead of injection or blow molding processing, with the advantage of producing a variety of shapes at low cost and reaching higher impact strength. The low tooling cost makes rotomolding an ideal process for prototype production for many applications, such as the study of liners for compressed natural gas (CNG) type IV (composite) filament-wound pressure vessels, as recommended in ISO 11439:001 - Gas cylinders-high pressure cylinders for the on-board storage of natural gas as a fuel for automotive vehicles ${ }^{2,3}$. Rotomolding process operates at low pressure and allows the production of complex tension-free samples compared to high pressure processes $^{4,5}$.

The rotomolding process requires a powdered or micronized polymer and thus some air bubbles can be entrapped in the molten polymeric material ${ }^{6}$. The process occurs by placing aggregates of thin granules on the heated surface of the mold and allowing for molecular diffusion between adjacent particles during polymer melting. The remaining empty spaces among the particles become air bubbles which are mostly eliminated in a later stage known as densification ${ }^{6,7}$. The air bubbles fraction yields a porosity in the material and affects the mechanical strength and density of the final product ${ }^{8,9}$.

The factors that influence the success of the rotomolding process include polymer particle size (usually within $150-500 \mu \mathrm{m}$ in diameter $)^{6,10}$, melting range, melting flow rate (MFR), molecular weight distribution and shrinkage. The suggested polymer MFR range for the rotomolding

*e-mail: ferreira.carlos@ufrgs.br process is commonly between $3.0-4.0 \mathrm{~g} / 10 \mathrm{~min}$, since lower MFR makes the melting flow inside the mold more difficult, leading to bubble formation. On the other hand, when polymer blends with crystallizable components are used, polymer miscibility must be taken into account along with melting and crystallization temperature, crystalline fraction, spherulites size and shape, and density ${ }^{11,12}$.

In this work, LLDPE/HDPE (linear low-density polyethylene/high density polyethylene) blends were studied aiming to produce liners for high-pressure composite vessels. The use of this polymeric blend instead of pure LLDPE, traditionally used for this application ${ }^{3}$, aims to improve overall processing and properties ${ }^{13-15}$. The study focuses on polyolefin blend composition with regard to miscibility, thermal behavior and rotomolding processability. The miscibility study is particularly needed considering that blend interfaces would be detrimental for the intended application.

\section{Experimental}

\subsection{Material}

The following materials were used: LLDPE laboratory grade DL $1002 \mathrm{RM}$, MFR of $3.3 \mathrm{~g} / 10 \mathrm{~min}\left(190{ }^{\circ} \mathrm{C} / 2.16 \mathrm{~kg}\right)$ and density of $0.939 \mathrm{~g} / \mathrm{cm}^{3}$; HDPE commercial grade GM $9450 \mathrm{~F}$ with wide (bimodal) molecular weight distribution, MFR of $0.38 \mathrm{~g} / 10 \mathrm{~min}\left(190{ }^{\circ} \mathrm{C} / 5.00 \mathrm{~kg}\right)$ and density of $0.952 \mathrm{~g} / \mathrm{cm}^{3}$. Both polymers were supplied by BRASKEM and micronized in usual disc mill. The average particle diameter as analyzed by laser granulometry (performed in a CILAS 1180 in ethanol) was $343.55 \mu \mathrm{m}$ for HDPE and $278.82 \mu \mathrm{m}$ for LLDPE. 


\subsection{Blend preparation and specimens}

In the first stage of this study, the LLDPE/HDPE mixture composition varied and LH05, LH10, LH20, LH30 and LH50 blends were prepared with 5, 10, 20, 30 and 50\% of HDPE, respectively. Prior to processing, the LLDPE and HDPE particles were manually mixed for 10 min using plastic bags. In the second stage, only the blend with the most suitable characteristics was used to produce liner prototypes of variable wall thicknesses, 1, 2, 3 and $4 \mathrm{~mm}$.

Blend specimens were obtained by extrusion/injection molding. Extrusion of the samples was performed in a single-screw extruder $(18 \mathrm{~mm})$, Ciola/MEP-18 brand with two heating zones operating at $190{ }^{\circ} \mathrm{C}$. The mixtures were later pelletized in an automatic SEIBT shredder and injection molded using a Thermo Scientific Haake Minijet II injector, with an injection pressure of 200 bar and cylinder/mold temperature of $200^{\circ} \mathrm{C} / 60^{\circ} \mathrm{C}$.

\subsection{Polymer liner prototype production}

The prototype liner was produced in a shuttle rotomolding equipment with $74 \mathrm{~L}$ capacity oven and the analyzed processing conditions were: temperature $\left(200\right.$ to $240{ }^{\circ} \mathrm{C}$ ), primary axis rotation (3 to $15 \mathrm{rpm}$ ), secondary axis rotation (5.3 to $23.1 \mathrm{rpm}$ ) and processing time (16 to $40 \mathrm{~min}$ ). A steel cylindrical mold $280 \mathrm{~mm}$ long, $78 \mathrm{~mm}$ in diameter and with $1000 \mathrm{~mL}$ inner volume was used. Temperature was monitored with a Rayon ST20 brand pyrometer and the most suited rotation speed was found to be $11 \mathrm{rpm}$ for the primary axis, and $19.5 \mathrm{rpm}$ for the secondary axis. The average heating rate in the $25^{\circ} \mathrm{C}$ to $250^{\circ} \mathrm{C}$ range was $17^{\circ} \mathrm{C} / \mathrm{min}$ and the average cooling rate was $13^{\circ} \mathrm{C} / \mathrm{min}$.

\subsection{Characterization}

The dynamic mechanical behavior of the pristine polyethylenes and their extruded/injected blends were analyzed in a TA Instruments DMA model Q800, with a dual cantilever support device, from $-150{ }^{\circ} \mathrm{C}$ to $100{ }^{\circ} \mathrm{C}$, using a heating rate of $2{ }^{\circ} \mathrm{C} / \mathrm{min}$ and $1 \mathrm{~Hz}$ oscillation frequency. DSC analysis of the polymers was carried out in a TA Instruments 2010 model, at heating rate of $10{ }^{\circ} \mathrm{C} \cdot \mathrm{min}^{-1}$. The rotomolded samples were analyzed under eight standard procedures (series) in order to evaluate multiple melting peaks as a function of the composition and the crystallization conditions. The endothermic curves were obtained in the second heating run. Table 1 summarizes the DSC test conditions. The first series consisted in heating and cooling the sample without annealing in order to obtain the crystallization and melting temperature ranges used as reference. The sample was kept for $60 \mathrm{~min}$ at each temperature level ${ }^{12}$.

Blend density of the rotomolded samples was measured using a pycnometer (ISO 1183-1:04 ${ }^{17}$ - Methods for determining the density of non-cellular plastics). Crystallinity of the micronized samples was evaluated with an X-ray diffractometer Siemens model D500. Scanning was carried out between $2 \theta=3-50^{\circ}$, using a $\mathrm{CuK} \alpha$ with $\lambda=1.5418 \AA$ radiation, at $40 \mathrm{kV}$ and $40 \mathrm{~mA}$. Apparent viscosity of the samples was evaluated in a capillary rheometer Kayeness model Galaxy III, and the melting flow rate was detemined in a Microtest Haake model 4105 B plastometer (ASTM D1238-1018 Standard test method for melt flow rates of thermoplastics by extrusion plastometer).

A hydrostatic test was used to determine the burst pressure of the rotomolded prototype liners. This test was carried out in a Flutrol equipment, 150 psi capacity, using two prototypes for each polymeric blend, according to ISO 11439:00 ${ }^{1}$ for pressure vessels. A HBM 1000 bar charge cell was used, with spindler 8 interface, HBM $60 \mathrm{~Hz}$, and the CATMAN 4.0 Professional software was employed for data processing.

\subsection{Determination of glass transition temperature, density and Flory interaction parameter}

The glass transition temperature $\left(T_{g A B}\right)$ of the blends was determined using the Fox Equation (Equation 1) ${ }^{13}$ :

Table 1. DSC experimental conditions used for blend thermal fractioning.

\begin{tabular}{|c|c|c|}
\hline $\begin{array}{c}\text { Series } \\
\text { number }\end{array}$ & Thermal treatment & Comment \\
\hline $1 \mathrm{st}$ & $\begin{array}{l}\text {-Heating from room temperature to } 160^{\circ} \mathrm{C} \text {; isothermal of } \\
5 \text { min. } \\
\text {-Cooling to } 50^{\circ} \mathrm{C} \text {; isothermal of } 3 \mathrm{~min} \text {. }\end{array}$ & $\begin{array}{l}\text {-Eliminate thermal history. } \\
\text {-Obtain crystallization temperature }\left(T_{c}\right) \text { and exothermic curve. }\end{array}$ \\
\hline 2nd & $\begin{array}{l}\text {-Heating from } 50 \text { to } 160^{\circ} \mathrm{C} \text {. } \\
\text {-Cooling to room temperature. }\end{array}$ & -Obtain melting temperature $\left(T_{m}\right)$ and endothermic curve. \\
\hline $3 \mathrm{rd}$ & $\begin{array}{l}\text {-Heating from } 50 \text { to } 145^{\circ} \mathrm{C} \text {; isothermal of } 5 \mathrm{~min} \text {. } \\
\text {-Cooling to } 50^{\circ} \mathrm{C} \text {; isothermal of } 3 \mathrm{~min} \text {. }\end{array}$ & -Obtain crystallization temperature $\left(T_{c}\right)$ and exothermic curve. \\
\hline 4 th & $\begin{array}{l}\text {-Heating from } 50 \text { to } 144{ }^{\circ} \mathrm{C} \text {. } \\
\text {-Cooling to room temperature. }\end{array}$ & -Obtain melting temperature $\left(T_{m}\right)$ and endothermic curve. \\
\hline 5 th & $\begin{array}{l}\text {-Heating from } 50 \text { to } 143{ }^{\circ} \mathrm{C} \text {; isothermal of } 5 \mathrm{~min} \text {. } \\
\text {-Cooling to } 50{ }^{\circ} \mathrm{C} \text {; isothermal of } 3 \mathrm{~min} \text {. }\end{array}$ & - Obtain crystallization temperature $\left(T_{c}\right)$ and exothermic curve. \\
\hline 6 th & $\begin{array}{l}\text {-Heating from } 50 \text { to } 142^{\circ} \mathrm{C} \text {. } \\
\text {-Cooling to room temperature. }\end{array}$ & - Obtain melting temperature $\left(T_{m}\right)$ and endothermic curve. \\
\hline 7 th & $\begin{array}{l}\text {-Heating from } 50 \text { to } 141^{\circ} \mathrm{C} \text {; isothermal of } 5 \mathrm{~min} \text {. } \\
\text {-Cooling to } 50{ }^{\circ} \mathrm{C} \text {; isothermal of } 3 \mathrm{~min} \text {. }\end{array}$ & -Obtain crystallization temperature $\left(T_{c}\right)$ and exothermic curve. \\
\hline 8 th & $\begin{array}{l}\text {-Heating from } 50 \text { to } 140{ }^{\circ} \mathrm{C} \text {. } \\
\text {-Cooling to room temperature. }\end{array}$ & -Obtain melting temperature $\left(T_{m}\right)$ and endothermic curve. \\
\hline
\end{tabular}


$\frac{1}{T_{g_{A B}}}=\frac{W_{A}}{T_{g_{A}}}+\frac{W_{B}}{T_{g_{B}}}$

where: $W_{A}$ and $W_{B}$ are the weight percentage of each component of the blends. The $T_{g A}$ and $T_{g B}$ data were obtained from DMA results.

Blend density $\left(\rho_{s}\right)$ was determined using Equation $2^{[11]}$ :

$W_{c}=\frac{1 / \rho_{s}-1 / \rho_{a}}{1 / \rho_{c}-1 / \rho_{a}} \times 100 \%$

where: $W_{c}$ is the crystallinity degree, $\rho_{c}$ and $\rho_{a}$ are the densities of fully crystalline polyethylene $\left(1.000 \mathrm{~g} / \mathrm{cm}^{3}\right)$ and fully amorphous polyethylene $\left(0.852 \mathrm{~g} / \mathrm{cm}^{3}\right)$, respectively. The melting enthalpy of the fully crystalline polyethylene was considered $218 \mathrm{~J} / \mathrm{g}^{[16]}$. The void content was later estimated based on the difference between density values obtained from Equation 2 and those found using pycnometry.

For the estimation of the entropic contribution values of the mixture defined by Gibbs' law, the Flory interaction parameter $\left(\chi_{12}\right)$ model based on the Flory-Huggins theory and modified by Nishi-Wang was used, according to Equation $3^{[13]}$

$\frac{1}{T_{m}}-\frac{1}{T_{m}^{o}}=\left(\frac{R}{\Delta H_{m}^{o}}\right) \cdot\left(\frac{V_{m c}}{V_{m a}}\right) \cdot\left(\omega_{a}\right)^{2} \cdot \chi_{12}$

where: $T_{m}^{o}$ is the melting absolute temperature of HDPE $(K)$ determined by DSC using a Hoffman-Weeks plot, $T_{m}$ is the melting temperature of the blend $(K), R$ is the universal gas constant $(8.314 \mathrm{~J} / \mathrm{mol} . \mathrm{K}), \Delta H_{m}^{o}$ is the melting enthalpy variation of HDPE as determined by DSC $(4.36 \mathrm{~kL} / \mathrm{mol}), V_{m c}$ is the molar volume of the crystalline polymer $\left(\mathrm{cm}^{3} / \mathrm{mol}\right)$, $V_{m a}$ the molar volume of the amorphous polymer $\left(\mathrm{cm}^{3} / \mathrm{mol}\right)$, $\omega_{a}$ the weight fraction of the LLDPE (lowest crystallinity degree). The molar volumes were considered 1.0 for the analyzed polymers since they have the same molecular structure, which only varies in their branches.

\section{Results and Discussion}

To determine the most suitable LLDPE/HDPE blend composition for liners, the thermal behavior was analyzed focusing on crystallite size profile aiming to obtain a more homogeneous liner wall. Table 2 shows the glass transition temperature of the neat polymers and their blends determined using DMA and the Fox equation. It is possible to note that $T_{g}$ of the blend increased with the addition of HDPE. It is also observed that the experimental $T_{g}$ values are very close to those calculated by Fox, which is indicative of miscibility of the polymers amorphous phase. In addition, the mixture was homogeneous throughout the compositional range evaluated.

Table 2 also shows the crystallinity degree and melting temperature of the rotomolded blends. The melting temperature $\left(T_{m}\right)$ remained nearly constant for all samples, and the $T_{m}$ determined after removing the thermal history showed values very close to those obtained in the first run. In addition, density of the samples increased with the crystallinity degree. Figure 1a shows this trend with the increase in HDPE content. Density of the LLDPE and HDPE resins before were 0.93 and $0.96 \mathrm{~g} / \mathrm{cm}^{3}$, respectively. Figure $1 \mathrm{~b}$ shows blend density evaluated by pycnometry of the rotomolded samples. It may be pointed out that these results are below the original values for LLDPE $\left(0.934 \mathrm{~g} / \mathrm{cm}^{3}\right)$ and HDPE $\left(0.952 \mathrm{~g} / \mathrm{cm}^{3}\right)$.

It may also be observed that LH05, LLDPE and LH10 samples showed higher density, indicating a lower amount of air bubbles produced during processing. Indeed, Figure 2 shows the approximate void content (bubbles) in the liner wall, which is indicative of its porosity degree due to processing.

Figure 3 shows the $\mathrm{X}$-ray spectra, evidencing the peaks attributed to 110 and 200 planes and the amorphous band
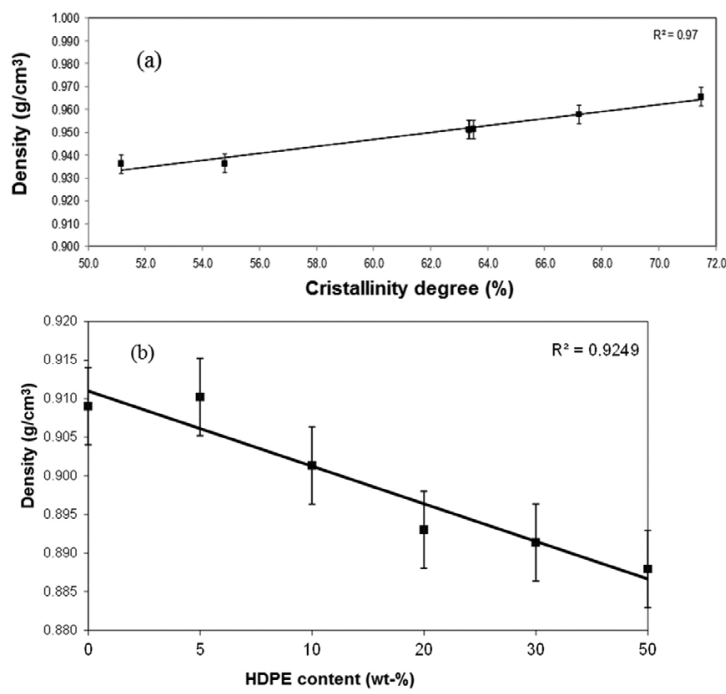

Figure 1. Variation of density of the LLDPE/HDPE blends obtained by picnometry: (a) before rotomolding and (b) after rotomolding.

Table 2. Glass transition temperature $\left(T_{g}\right)$ obtained with distinct methods, melting temperature $\left(T_{m}\right)$ and crystallinity degree $\left(W_{c}\right)$ of the samples.

\begin{tabular}{lccccc}
\hline Sample & $\begin{array}{c}\mathbf{T}_{\mathbf{g}}\left({ }^{\circ} \mathbf{C}\right) \\
\text { DMA }\end{array}$ & $\begin{array}{c}\mathbf{T}_{\mathbf{g}}\left({ }^{\circ} \mathbf{C}\right) \\
\mathbf{F o x}\end{array}$ & $\begin{array}{c}\mathbf{T}_{\mathbf{m}}\left({ }^{\circ} \mathbf{C}\right) \\
\mathbf{1}^{\text {st }} \mathbf{r u n}\end{array}$ & $\begin{array}{c}\mathbf{T}_{\mathbf{m}}\left({ }^{\circ} \mathbf{C}\right) \\
\mathbf{2}^{\text {nd }} \mathbf{r u n}\end{array}$ & $\begin{array}{c}\mathbf{W}_{\mathbf{c}} \\
(\boldsymbol{\%})\end{array}$ \\
\hline LLDPE & -119.3 & - & 126.5 & 127.4 & 51.2 \\
LH05 & -117.7 & -119.1 & 126.3 & 125.8 & 55.0 \\
LH10 & -114.9 & -118.8 & 127.6 & 127.0 & 63.3 \\
LH20 & -115.4 & -118.4 & 127.4 & 126.8 & 63.3 \\
LH30 & -116.3 & -118.0 & 127.9 & 127.2 & 63.5 \\
LH50 & -115.2 & -117.2 & 128.1 & 127.5 & 67.2 \\
HDPE & -115.0 & - & 128.8 & 131.0 & 71.5 \\
\hline
\end{tabular}


region for $L L D P E, H D P E$ and their blends (LH05 and LH50). A decrease in peak intensity is observed for higher $L L D P E$ content, indicating a decrease in crystallinity. The micronized blend samples presented two very intense peaks between $13^{\circ}$ and $27^{\circ}$, showing the same behavior of polyethylene. Table 3 shows the intensity of the identified crystalline peaks (planes 110 and 200) in the diffractogram of LLDPE, HDPE and the blends with 5\% and 50\% of HDPE. Crystallinity was obtained by numerical integration, applying Simpson's 3/8 rule. Integration was performed over amorphous and crystalline curves, within $2 \theta=13-27^{\circ}$, with an average truncation error of $6.0 \times 10^{-4} \%$. Crystallinity values were closer for the samples having higher HDPE content, or higher crystallinity degree (shown in Table 2).

Table 4 shows Flory parameter results, which indicates phase stability of the blends. The LH05 and LH50 samples displays the most negative values, suggesting that these blends present greater miscibility.

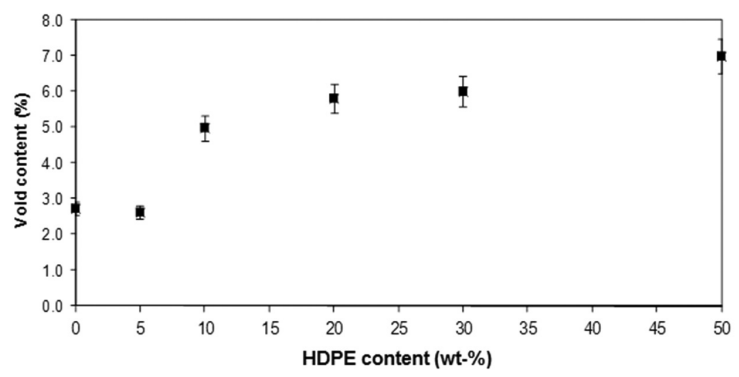

Figure 2. Variation of void content for the polymeric blends.

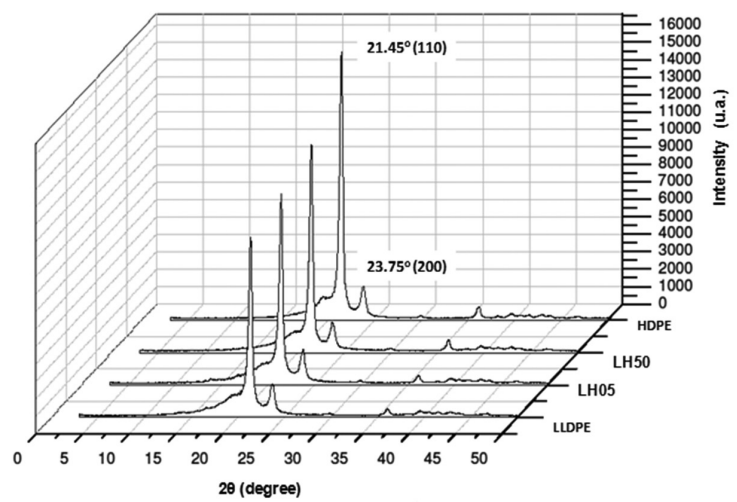

Figure 3. X-Ray spectra of the blends and the neat polymers.

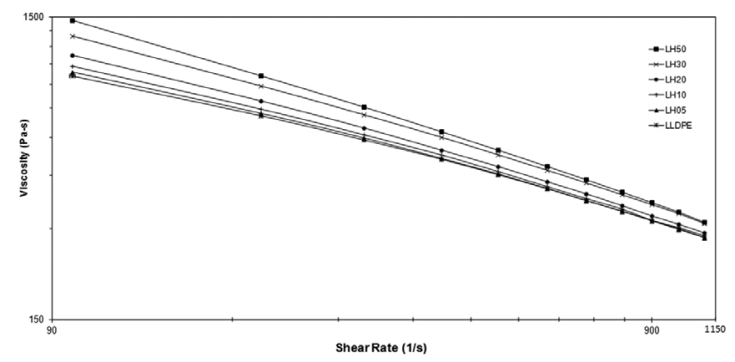

Figure 4. Variation of apparent viscosity with shear rate for the samples.
The LH05 and LH10 blends showed MFR higher than $3.0 \mathrm{~g} / 10 \mathrm{~min}$, which are in the optimum range regarding processability as suggested by the rotomolding companies. As shown in Figure 4, the apparent viscosity of these two blends were similar to that of neat LLDPE, within $5 \%$ variation, which is also an indication of their suitability regarding processability.

Figure 5 shows the results of the hydrostatic pressure test of the prototype liner for all blend compositions. The average error variability of the samples was of c.a. $8 \%$. The LH05 and LH50 samples showed the highest burst pressure levels. Even though the LH50 blend showed the highest hydrostatic rupture pressure, it yielded higher void content, at both inner and outer surfaces, indicating low reliability for this material. Therefore, the combined analysis of void content, burst pressure and processability (MFR) indicates that the best overall performance was found for the LH05 blend.

The effect of varying the wall thickness of the prototype on its burst pressure was evaluated for the blend which showed the best performance (i.e. 5\% HDPE content). Figure 6 shows these results and, as expected, the largest wall thickness $(5 \mathrm{~mm})$ yielded the highest burst pressure.

Table 3. Peak intensity and crystallinity degree values obtained by X-Ray.

\begin{tabular}{lccc}
\hline Sample & $\begin{array}{c}\text { Plane 110 } \\
\text { (u.a.) }\end{array}$ & $\begin{array}{c}\text { Plane 200 } \\
\text { (u.a.) }\end{array}$ & $\begin{array}{c}\text { Crystallinity } \\
\text { degree (\%) }\end{array}$ \\
\hline LLDPE & 10329 & 1901 & 58.4 \\
LH05 & 10965 & 2045 & 60.2 \\
LH50 & 11890 & 1704 & 66.9 \\
HDPE & 15375 & 1918 & 71.9 \\
\hline
\end{tabular}

Table 4. Flory interaction parameter values for the blends.

\begin{tabular}{ccc}
\hline Blend & $\begin{array}{c}\text { Temperature } \\
\boldsymbol{T}_{\boldsymbol{m}}\left({ }^{\circ} \mathbf{C}\right)\end{array}$ & $\begin{array}{c}\text { Flory Interaction } \\
\text { parameter } \\
\chi_{\mathbf{1 2}}\end{array}$ \\
\hline LH05 & 126.3 & -0.00894 \\
LH10 & 127.6 & -0.00523 \\
LH20 & 127.4 & -0.00723 \\
LH30 & 127.9 & -0.00624 \\
LH50 & 128.1 & -0.00950 \\
\hline
\end{tabular}

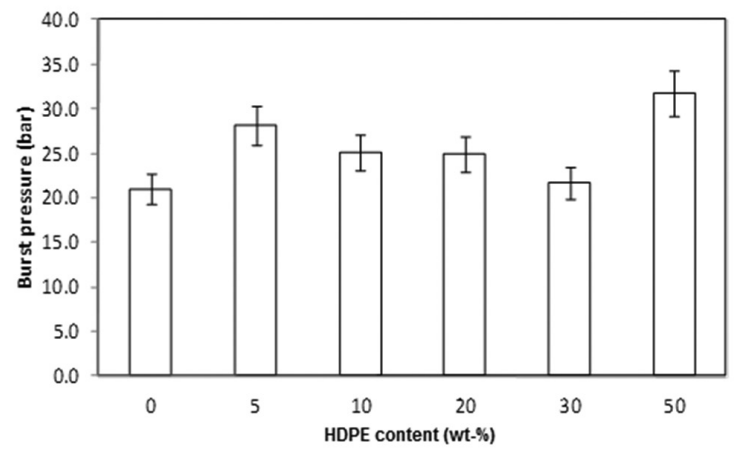

Figure 5. Burst pressure results of the liners produced with the blends (wall thickness $=5 \mathrm{~mm}$ ). 


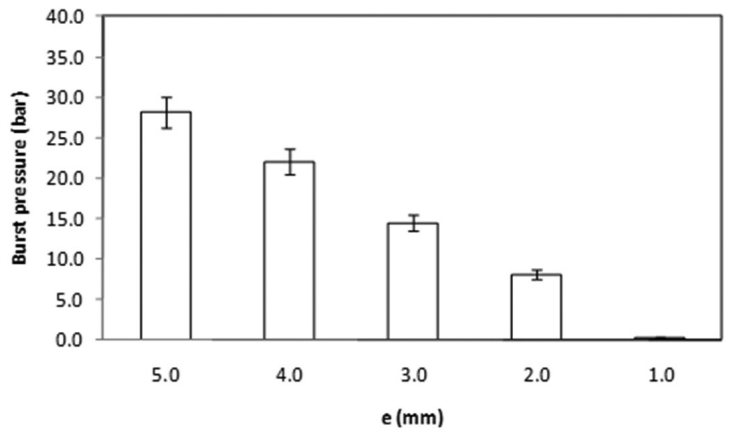

Figure 6. Variation of burst pressure of the liner with thickness for the LH05 polymeric blend.

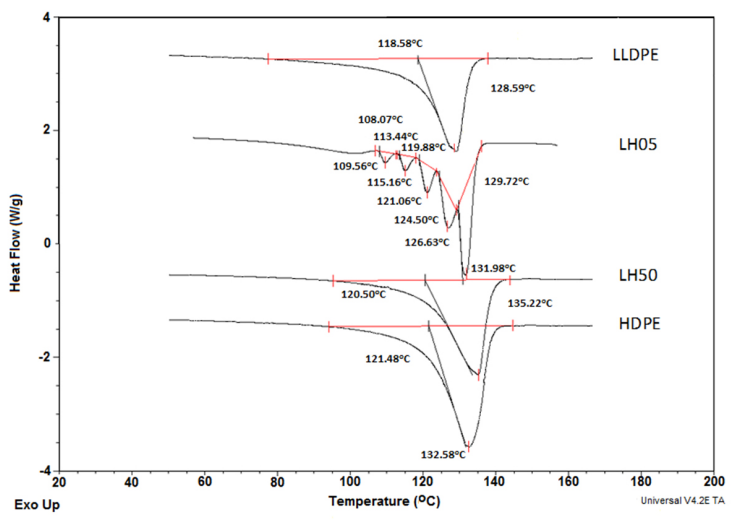

Figure 7. Comparison of the fractioning of LH05, LH50, LLDPE and HDPE.

Figure 7 shows the melting fractioning of LLDPE, HDPE, LH05 and LH50 by DSC. It is possible to observe that the LH50 and HDPE samples show higher melting temperature and more difficult crystallization. Figure 8 presents the equilibrium melting temperature $\left(T_{m}^{o}\right)$ for the LH05 blend using the Hoffman-Weeks plot method obtained from DSC.

Figure 9 presents the results of the DMA analysis of the LH05 sample. The $T_{g}$ (obtained from Tan $\delta$ ) was $-117.7^{\circ} \mathrm{C}$ and the storage modulus was 751.6 MPa. For comparison, the LLDPE and HDPE storage moduli were $710.5 \mathrm{MPa}$ and $1086 \mathrm{MPa}$, respectively. The loss modulus curve shows the $\gamma$ relaxation (crankshaft motion) between $-120{ }^{\circ} \mathrm{C}$ and $-150{ }^{\circ} \mathrm{C}$ and the $\beta$ relaxation at $-10.6{ }^{\circ} \mathrm{C}$. These results indicate the $\mathrm{LH} 05$ blend to be miscible and suitable for the proposed application.

\section{Conclusions}

The behavior of the studied blends was analyzed in order to define the most appropriate blend composition for the intended pressure vessel application. Variation in HDPE content of the blend was responsible for changing

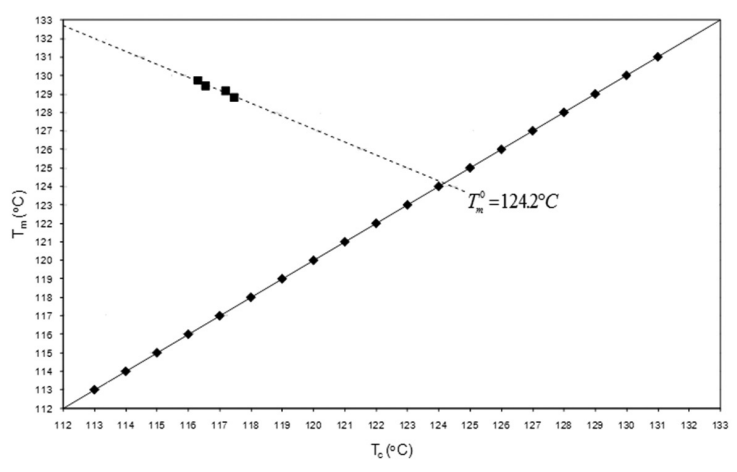

Figure 8. Hoffman-Weeks plot of LH05 blend with equilibrium melting temperature $T_{m}^{o}=124.2^{\circ} \mathrm{C}$.

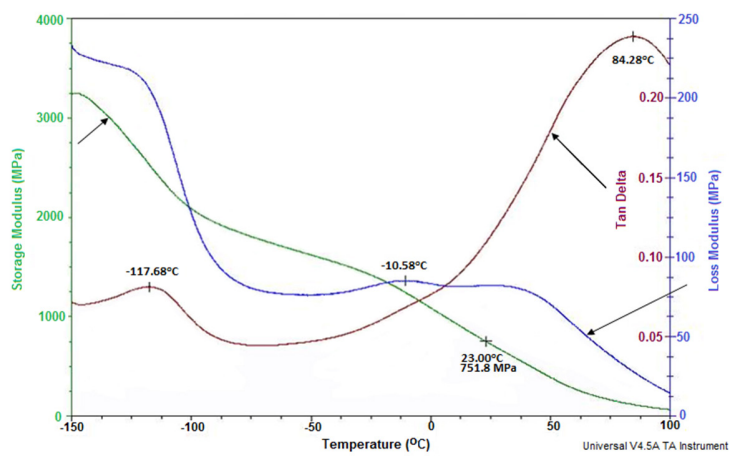

Figure 9. DMA analysis of the LH05 blend.

temperature and processing time of the rotomolded liners, yielding different porosity contents for the studied blends.

It was found that crystallinity degree and density increased with the HDPE content in the polymeric blend after rotomolding. Comparing the density results obtained by pycnometry and DSC, the void content increased with the HDPE content in the blend. LLDPE and the blends with 5 and $10 \%$ of HDPE presented the highest melting flow rate, yielding better rotomolding processing performance. Determination of the Flory-Huggins interaction parameter using Nishi-Wang equations indicates that the blends should be considered miscible. A fair agreement between experimental $T_{g}$ data and that from the Fox equation is another sign of miscibility of the amorphous phase. In all, the blend with 5\% HDPE yielded the best combination of processability and properties considering its use as polymeric liner for composite pressure vessels.

\section{Acknowledgements}

The authors would like to thank FINEP and CNPq for the financial support, and CEFET-RS, Braskem, Poplast, and Plastecnica for their help. 


\section{References}

1. International Standards Organization - ISO. ISO 11439:00: Gas Cylinders-High Pressure Cylinders for the On-Board Storage of Natural Gas as a Fuel for Automotive Vehicles. ISO; 2000.

2. Bellehumeur CT and Tiang JS. Simulation of non-isothermal melt densification of polyethylene in rotational molding. Polymer Engineering \& Science. 2002; 42:215-229. http:// dx.doi.org/10.1002/pen.10942

3. Velosa JC, Nunes JP, Antunes PJ, Silva JF and Marques AT. Development of a new generation of filament wound composite pressure cylinders. Composites Science and Technology. 2009; 69:1348-1353. http://dx.doi.org/10.1016/j. compscitech.2008.09.018

4. Barboza ES, Chludzinski M, Costa AD, Ferreira CA and Amico SC. Liner of PEMD/PEAD polymeric blend for pressure vessels submitted to hydrostatic burst test. In: Anais do $10^{\circ}$ Congresso Brasileiro de Polímeros - CBPOL; 2009; Foz do Iguaçu. ABPol; 2009.

5. Li Y, Liang JC, Zhang W, Qi W, Su M and Liu CD. Study on process and impact strength for a rotationally molded truck fender. Journal of Materials Processing Technology. 2007; 187-188:492-496. http://dx.doi. org/10.1016/j.jmatprotec.2006.11.142

6. Kontopoulou M and Vlachopoulos J. Melting and densification of thermoplastics powders. Polymer Engineering \& Science. 2001; 41:155-169. http://dx.doi.org/10.1002/ pen. 10718

7. Liu S and Fu K. Effect of enhancing fins on the heating/cooling efficiency of rotational molding and the molded product qualities. Polymer Testing. 2008; 27:209-220. http://dx.doi. org/10.1016/j.polymertesting.2007.10.004

8. Gogos G. Bubble removal in rotational molding. Polymer Engineering \& Science. 2004; 44:388-394. http://dx.doi. org/10.1002/pen.20035

9. Frank A, Pinter G and Lang RW. Prediction of the remaining lifetime of polyethylene pipes after up to 30 years in use. Polymer Testing. 2009; 28:737-745. http://dx.doi.org/10.1016/j. polymertesting.2009.06.004
10. Cramez MC, Oliveira MJ and Crawford RJ. Optimisation of rotational moulding of polyethylene by predicting antioxidant consumption. Polymer Degradation and Stability. 2002; 75:321-327. http://dx.doi.org/10.1016/S01413910(01)00234-8

11. Conti DS, Yoshida MI, Pezzin SH and Coelho LAF. Phase behavior of poly(3-hydroxybutyrate)/poly (3-hydroxybutyrate-co-3-hydroxyvalerate) blends. Fluid Phase Equilibria. 2007; 261:79-84. http://dx.doi.org/10.1016/j. fluid.2007.07.022

12. Camargo M, Forte MMC and Wolf CR. Linear Low Density Polyethylene Thermal Fractionation by DSC Technique. International Journal of Polymer Analysis and Characterization. 2008; 13:49-65. http://dx.doi. org/10.1080/10236660701802593

13. Munaro M and Akcelrud L. Polyethylene blends: A correlation study between morphology and environmental resistance. Polymer Degradation and Stability. 2008; 93:43-49. http:// dx.doi.org/10.1016/j.polymdegradstab.2007.10.017

14. Liang S, Yang H, Wang K, Zhang Q, Du R and Fu Q. Unique crystal morphology and tensile properties of injection-molded bar of LLDPE by adding HDPE with different molecular weights. Acta Materialia. 2008; 56:50-59. http://dx.doi. org/10.1016/j.actamat.2007.09.008

15. Lo C, Seifert S, Thiyagarajan $\mathrm{P}$ and Narasimhan B. Phase behavior of semicrystalline polymer blends. Polymer. 2004; 45:3671-3679. http://dx.doi.org/10.1016/j. polymer.2004.03.089

16. Canevarolo SV. Technical of polymers characterization. São Paulo: Artliber; 2004.

17. International Standards Organization - ISO. ISO 1183-1:04: Methods for Determining the Density of Non-Cellular Plastics. ISO; 2004.

18. American Society for Testing and Materials - ASTM. ASTM D1238-10: Standard Test Method for Melt Flow Rates of Thermoplastics by Extrusion Plastometer. ASTM; 2010. 